\title{
Spiral swimming behavior due to cranial and vertebral lesions associated with Cytophaga psychrophila infections in salmonid fishes
}

\author{
Michael L. Kent ${ }^{1, *}$, J. M. Groff ${ }^{2}$, J. K. Morrison ${ }^{3}$, W. T. Yasutake ${ }^{4}$, R. A. Holt ${ }^{5}$ \\ ${ }^{1}$ Battelle Marine Science Laboratory, 439 West Sequim Bay Road, Sequim, Washington 98382, USA \\ ${ }^{2}$ Department of Medicine, School of Veterinary Medicine, University of California, Davis, California 95616, USA \\ ${ }^{3}$ Olympia Fish Health Center, 2625 Parkmount Ln., Bldg. A., Olympia, Washington 98502, USA \\ ${ }^{4}$ U.S. Fish and Wildlife Service, Seattle National Fishery Research Center, Bldg. 204 Naval Station, Seattle, Washington 98115, \\ USA \\ ${ }^{5}$ Oregon Department of Fish and Wildlife, Department of Microbiology, Oregon State University, Corvallis, Oregon 97331 , \\ USA
}

\begin{abstract}
Cytophaga psychrophila (Order Cytophagales) infections of the cranium and anterior vertebrae in salmonid fishes were associated with ataxia, spiral swimming along the long axis of the fish, and death. The syndrome was observed in 2 to $10 \%$ of underyearling coho salmon Oncorhynchus kisutch, rainbow trout Salmo gairdneri, and steelhead trout S. gairdneri at several private, state, and federal hatcheries in Washington and Oregon, USA. Affected fish did not recover and ultimately died. Histological examination of affected fish consistently revealed subacute to chronic periostitis, osteitis, meningitis, and ganglioneuritis. Inflammation and periosteal proliferation of the anterior vertebrae at the junction of the vertebral column with the cranium with extension into the cranial case was a consistent feature of the disease. The adjacent nervous tissue, particularly the medulla, was often compressed by the proliferative lesion and this may have caused the observed ataxia. Though bacteria were seldom observed in these lesions, C. psychrophila was isolated in culture from the cranial cavity of all affected fish that were tested. Epizootiological observations suggested that the bacterium is the etiologic agent of the disease because the spiral swimming behavior and lesions were only observed in populations which had recovered from acute C. psychrophila infections, known as 'cold-water disease'
\end{abstract}

\section{INTRODUCTION}

Cytophaga psychrophila (Order Cytophagales), the causative agent of cold-water disease, is a wide-spread pathogen of cultured salmonid fishes in North America (Pacha \& Ordal 1970, Schachte 1983). Epizootics typically occur at between 4 and $15^{\circ} \mathrm{C}$ in underyearling fish (Conrad \& DeCew 1967), but yearling coho Oncorhynchus kisutch and chinook salmon $O$. tshawytscha may also be affected (Holt 1972, Wood 1974). The bacteria often infected the external surfaces, resulting in ulceration of the dermis and necrosis of the underlying muscle (Wolke 1975). The disease may also progress to septicemia with necrosis observed in internal organs (Wolke 1975), and bacteria can be isolated from these

\footnotetext{
- Present address: Department of Fisheries and Oceans, Pacific Biological Station, Nanaimo, B.C., Canada V9R 5K6
}

infected tissues (Wood 1974). Though Wood \& Yasutake (1956) reported little inflammatory response in the visceral organs, Borg (1960) reported a mild mononuclear infiltration associated with the disease.

A chronic form of the infection resulting in lordosis and scoliosis was observed in juvenile coho salmon (Conrad \& DeCew 1967, Holt 1972), and Wood (1974) surmised that these lesions were caused by bacterial destruction of muscle bundles adjacent to vertebrae which resulted in unequal tension on the spinal column. Spiral swimming behavior has been observed in fish from hatcheries where cold-water disease is enzootic (Yasutake 1965), and we have observed this syndrome at several hatcheries in Oregon and Washington, USA. Presented here are histological, bacteriological, and epizootiological data that indicate that this ataxic swimming behavior was due to chronic inflammation in the cranial cavity and anterior vertebrae associated with C. psychrophila infections. 


\section{MATERIALS AND METHODS}

The primary subjects of this investigation were juvenile coho salmon Oncorhynchus kisutch reared at a freshwater hatchery in Washington State, USA. These fish were examined from 29 May to 11 June 1987. In addition, occurrences of this disease in government hatcheries in Oregon and Washington are reported (Table 1) to indicate the geographical distribution of the syndrome.

Histopathology. The anterior third of the body and visceral organs of 27 juvenile coho salmon exhibiting spiral swimming behavior along the long axis were fixed in Davidson's solution (Humason 1979). Tissues were decalcified in a formic acid-citric acid solution and then processed using standard histological techniques (Luna 1968). Sections were stained with Harris' haematoxylin and eosin, Brown and Bremn Gram stain, Warthin-Starry silver stain, Periodic acid-Schiffs (PAS) stain, Heldenhain's stain for osteoid, or the Giemsa stain (Luna 1968). Ten clinically normal fish from a raceway containing effected fish were also examined.

Bacteriology. Tissues from the posterior of the cranial space of 11 affected and 6 clinically normal fish were cultured for bacteria by anesthetizing the fish with MS-222, disinfecting the surface of the head with $70 \%$ ethanol, and aseptically opening the cranial case. Inocula were then obtained from the posterior region of the cranium with calcium alginate swabs. Inocula were

Table 1 Occurrence of spiral swimming behavior in salmonid fishes associated with cerebral and anterior vertebral lesions in Washington (WA) and Oregon (OR), USA, with year when condition was first recognized

\begin{tabular}{|c|c|c|}
\hline Species & Location & Year \\
\hline $\begin{array}{l}\text { Oncorhynchus } \\
\text { kisutch }\end{array}$ & $\begin{array}{l}\text { Willard federal } \\
\text { hatchery, WA }\end{array}$ & 1963 \\
\hline O. kisutch & $\begin{array}{l}\text { Quilcene federal } \\
\text { hatchery, WA }\end{array}$ & 1963 \\
\hline O. kisutch & $\begin{array}{l}\text { Nehalem state } \\
\text { hatchery, OR }\end{array}$ & 1980 \\
\hline O. kisutch & $\begin{array}{l}\text { Sandy state } \\
\text { hatchery, OR }\end{array}$ & 1981 \\
\hline O. kisutch & $\begin{array}{l}\text { Little White Salmon } \\
\text { federal hatchey, WA }\end{array}$ & 1986 \\
\hline O. kisutch & $\begin{array}{l}\text { Makah federal } \\
\text { hatchery, WA }\end{array}$ & 1986 \\
\hline O. kisutch & $\begin{array}{l}\text { Humptulips state } \\
\text { hatchery, WA }\end{array}$ & 1987 \\
\hline O. kisutch & $\begin{array}{l}\text { Willapa state } \\
\text { hatchery. WA }\end{array}$ & 1987 \\
\hline O. kisutch & $\begin{array}{l}\text { A private hatchery. WA } \\
\text { (present study) }\end{array}$ & 1987 \\
\hline Salmo gairdnen & $\begin{array}{l}\text { Quilcene federal } \\
\text { hatchery, WA. }\end{array}$ & 1984 \\
\hline S. gaurdneri & $\begin{array}{l}\text { Chambers Creek state } \\
\text { hatchery, WA }\end{array}$ & 1987 \\
\hline
\end{tabular}

streaked on charcoal agar (Daly \& Stevenson 1985) or Tryptic Soy Agar (Difco) and cultured at $15^{\circ} \mathrm{C}$ and at room temperature.

Bacterial isolates were tested for their serological relatedness to Cytophaga psychrophila and Flexibacter columnaris using slide agglutination. tests with the appropriate antisera, diluted to $1: 50$. The antisera to $C$. psychrophila and $F$. columnaris were obtained from the fish disease laboratory, Department of Microbiology, Oregon State University, Corvallis, Oregon, USA.

\section{RESULTS}

\section{Clinical signs and mortality}

Coho salmon reared at a private hatchery in Washington showing spiral swimming behavior along the long axis and loss of equilibrium first exhibited mortality when they weighed ca $5 \mathrm{~g}$. As the disease progressed the fish often remained motionless on their sides at the water surface until agitated, when they would resume erratic swimming. Affected fish did not recover and typically died 3 to $5 \mathrm{~d}$ after the clinical signs were first observed. Some affected fish displayed dark pigmentation on either the right or left longitudinal half of the body and others occasionally exhibited dorsal swelling posterior to the skull. Fish were initially maintained at $15^{\circ} \mathrm{C}$. The temperature was lowered to $10^{\circ} \mathrm{C}$ ca 2 mo after onset of the disease and this apparently did not affect the course of the disease. In 1987 , ca $2 \%$ of the underyearling coho at this hatchery exhibited these clinical signs, and all affected fish eventually died. The condition persisted in this population for several months and fish were submitted for necropsy at $14 \mathrm{~g}$ (avg. wt).

\section{Histopathology}

Histological examination of affected fish revealed subacute and chronic periostitis, osteitis, meningitis, and ganglioneuritis (Figs. 1 to 4). Inflammation and periosteal proliferation of the vertebrae at the junction of the vertebral column and the caudal limit of the cranium were observed in all fish. The lesions often extended anteriorly into the caudal aspect of the cranium resulting in subacute meningitis. The adjacent neural tissue, particularly the medulla, was often compressed and had secondary necrosis and hemorrhage (Figs. 1 and 2). The posterior cranial nerves and anterior - most spinal nerves were commonly affected (Fig. 3). Inflammation often extended into the connective tissue stroma peripheral to the auditory canal and into the muscle bundles adjacent to the anterior vertebrae. The mixed inflammatory infiltrate consisted of mononuclear 


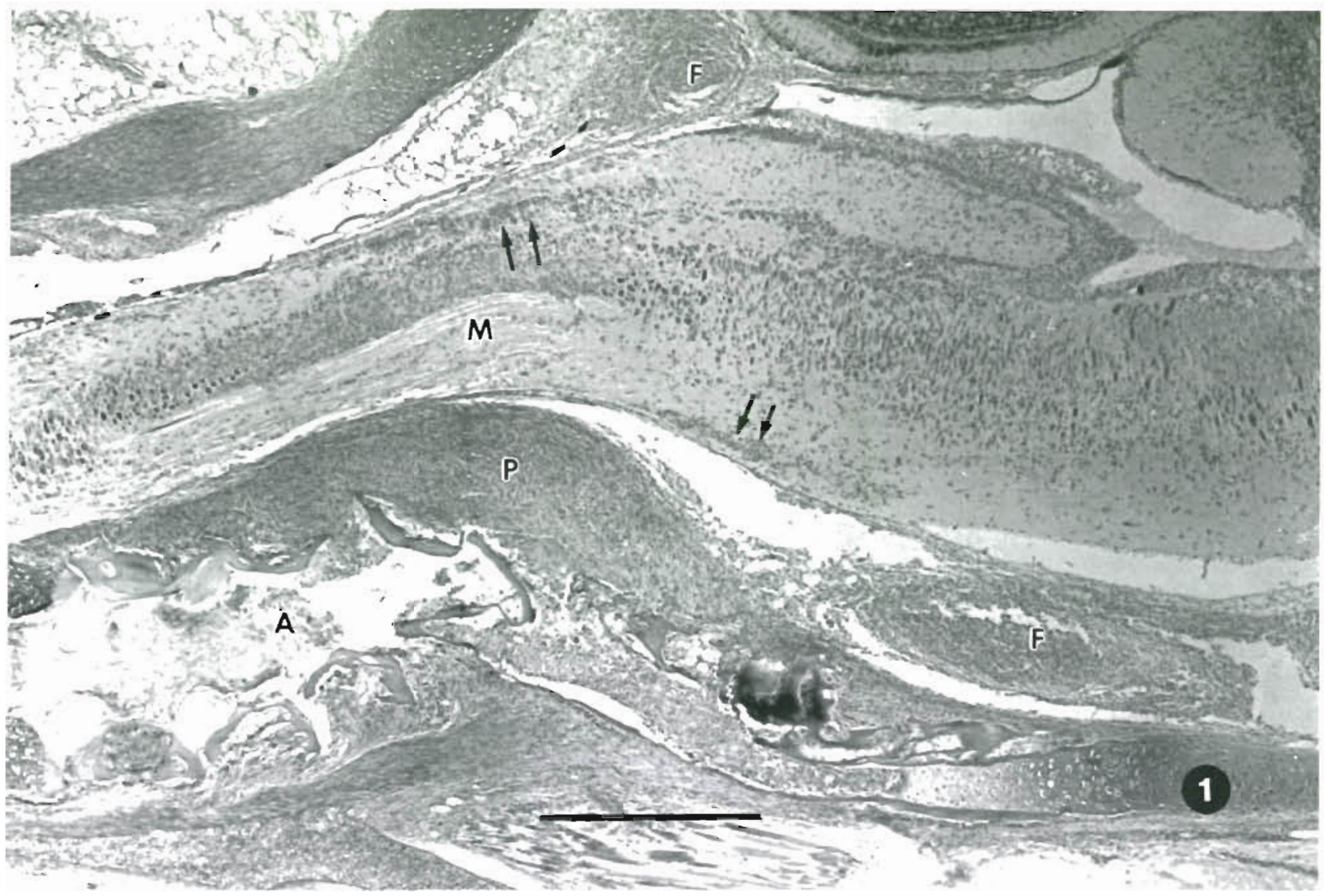

Fig. 1 Oncorhynchus kisutch. Posterior aspect of the cranial cavity with periosteal proliferation and inflammation (P) of the anterior vertebrae (A) with extension into the cranial cavity. The junction of the medulla (M) and the spinal cord is apparently compressed with areas of hemorrhage (arrows). The lesion encircles the medulla as indicated by focl at the dorsal and ventral aspects $(F)$ H \& E Bar $=250 \mu \mathrm{m}$

inflammatory cells and polymorphonuclear leukocytes. Heidenhain's stain for osteoid revealed foci of osteond formation within areas of periosteal proliferation.

In one specimen, there was inflammation of the connective tissue stroma of the ventral pharyngeal area (Figs. 4 and 5). The lesion was centered around bony elements of the gill arches undergoing endochondral ossification with destruction of the bony elements

Special stains of the coho salmon tissues from this study group did not reveal bacterial organisms associated with the lesions. However, Giemsa-stained sections from a coho salmon exhibiting identical lesions from the Willipa state fish hatchery in Washungton (Table 1) revealed numerous filamentous bacteria in a lesion involving the notochord (Fig. 6)

\section{Bacteriology}

Cytophaga psychrophila was isolated from the cranial samples of all affected fish examined on both media. The density of colonies on the plates in the initial isolations varied dramatically between fish whereas only 3 or 4 colonies were isolated from some fish, other plates revealed numerous Cytophaga colonses into the tertiary streak. Consistent with $C$ psychrophla, the colonjes were yellow and the bacteria were Gram-negatıve filamentous rods that did not grow at $25^{\circ} \mathrm{C}$. Furthermore, a representative isolate cross-reacted serologically with C. psychrophila antiserum at 150 on a slide agglutunation test

\section{Epizootiology}

Coho salmon, steelhead trout Salmo gardnen and rambow trout $S$. gardnen at several government hatcheries in Washington and Oregon exhibited similar clinical and histological changes, and these locations are listed in Table 1 The table was compled trom observations made by personnel of the United States Fish and Wildlife Service ( $J$ Mornson, W Yasutake) and the Oregon Department of Fashenes ( $R$ Holt) Usually 1 to $2 \%$ of the fish at these hatcheres were 


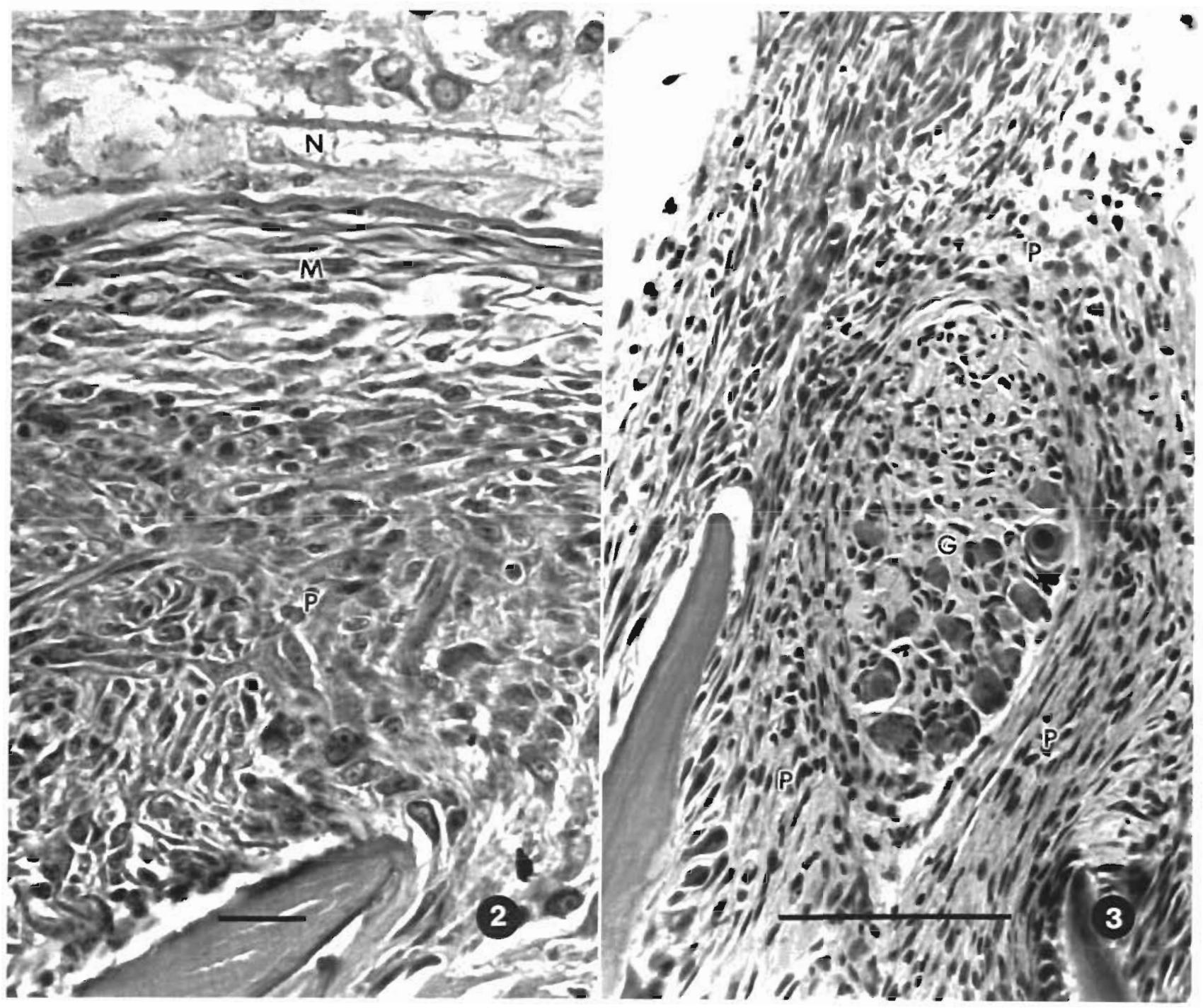

Figs. 2 and 3. Oncorhynchus kisutch. Fig. 2. High magnification of the lesion adjacent to the medulla. There is periosteal proliferation and inflammation (P) with extension through the meninges $(\mathrm{M})$ to the adjacent nervous tissue $(\mathrm{N})$. $\mathrm{H} \& \mathrm{E}$. Bar $=$ $25 \mu \mathrm{m}$. Fig. 3. Periosteal proliferation and inflammation (P) surrounding a neural ganglion (G) in the posterior cranium. H. \& E. Bar $=100 \mu \mathrm{m}$

affected, but at the Sandy and Nehalem hatcheries in Oregon ca $10 \%$ of the fish died with this syndrome in 1980 and 1981

\section{DISCUSSION}

The cranial and vertebral lesions were most likely the cause of the ataxia observed in affected salmon. The subacute to chronic proliferative lesions involving the cranium and anterior vertebrae, and associated lesions in the adjacent neural tissue, were observed in a]l the fish examined that exhibited the spiral swimming behavior. The hind brain is important in motor control and, therefore, the histological lesions corre- sponded well with clinical signs. Furthermore, involvement of cranial ganglia associated with the auditory canal may have been contributing factors.

Bacteriological and epizootiological evidence supports the hypothesis that Cytophaga psychrophila is the causative agent of the disease. To our knowledge, C. psychrophila is enzootic at all of the hatcheries where we have observed the cranial lesions. Moreover, the disease reported here usually occurred in fish which had recently recovered from the typical form of the infection, referred to as cold-water disease. Bacterial cultures from the cranium of affected fish consstently revealed the organism, whereas cultures from fish without the lesions from the same water system revealed no bacteria. Some cultures contained as few 


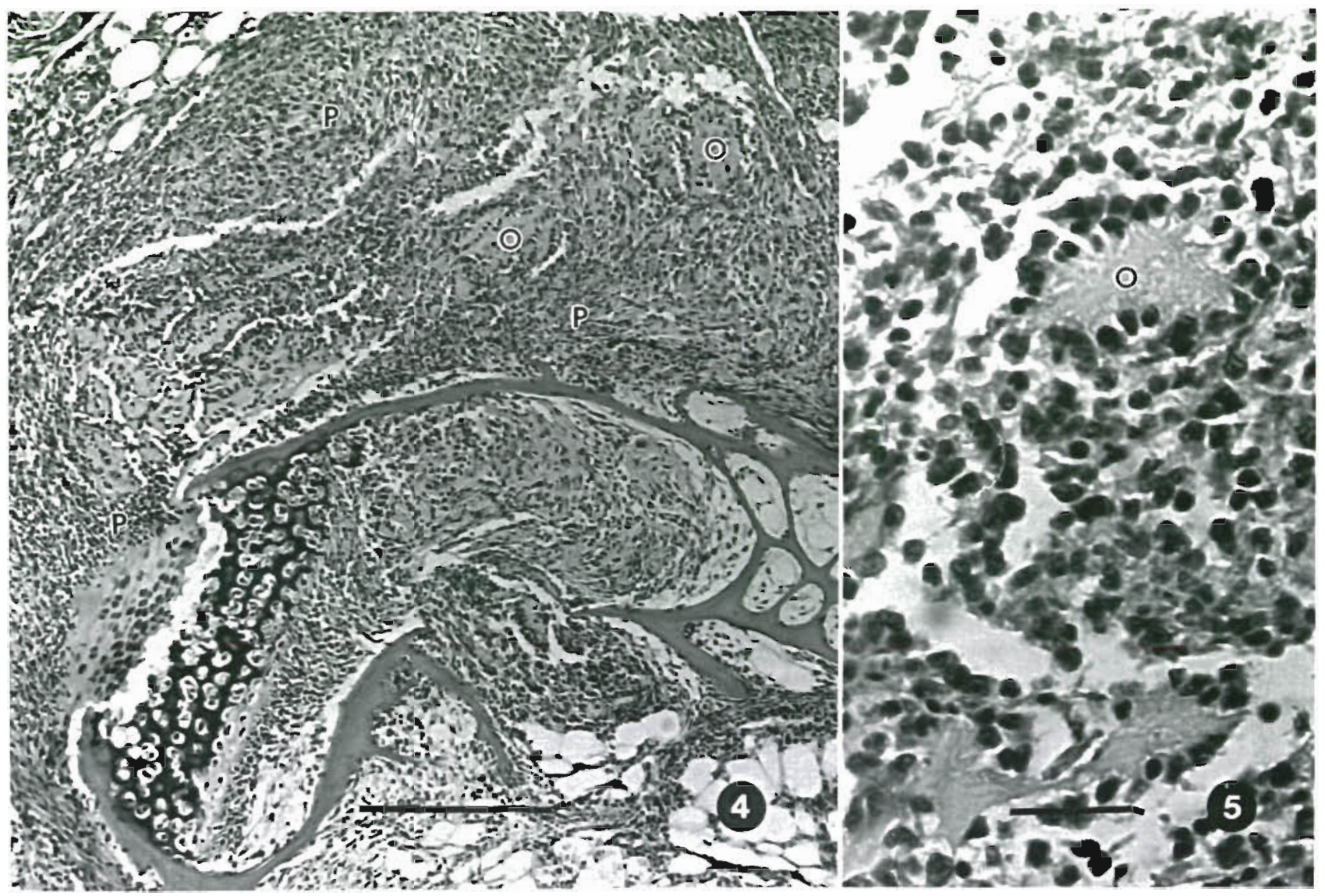

Figs. 4 and 5. Oncorhynchus kisutch. Fig. 4. Periosteal proliferation (P), inflammation, and degenerative osteoid (O) in the third gill arch. Note extension of the inflammation involving the center of the bone undergoing endochondral ossification. $\mathrm{H} \& \mathrm{E}$. Bar $=$ $250 \mathrm{um}$. Fig. 5. High magnification in an area of periosteal proliferation showing osteoblasts surrounding osteoid (O) H. \& E. Bar $=$ $25 \mathrm{um}$

as 3 bacterial colonies, which would account for the inability to detect the organisms in most tissue sections.

Similar clinical signs have not been reported in experimentally induced infections (Otis 1984). In one attempt, Holt (1987) was not able to produce the cranial lesions or spiral swimming behavior in fish inoculated subcutaneously with an isolate obtained from the brain of a fish exhibiting this behavior, but typical 'coldwater' disease and mortality was induced in $88 \%$ of the exposed fish. This may indicate that specific conditions are required to cause this chronic infection or that only a small percentage of fish infected with Cytophaga psychrophila develop these lesions. C. psychrophila may be transmitted with eggs (Borg 1960, Schachte 1983) and fish can be infected at essentially any age (Holt 1972). The time of initial exposure may be critical for ultimate development of chronic forms of the infection. Hatcheries usually treat fish affected with coldwater disease with oxytetracycline. Possibly the lesions reported in the present study, and presumably the concurrent bacterial infection, are initiated at sites that accumulate relatively small amounts of the antibiotic Initial observations indicate that further treatment with antibiotics, including oxytetracycline, is not efficacious in treating this chronic form of the bacterial infection and that affected fish ultimately die.

The periosteum associated with the central nervous system appeared to be the primary site of infection. Infectious agents and inflammatory processes may take 4 routes to the nervous system; by invasion of peripheral nerves, by direct extension from adjacent structures, by a hematogenous route or by direct implantation from a penetrating injury (Jubb et al. 1985). All but the latter are possible methods by which the cranial infections were established; ganglia were often involved, extension of the inflammation from adjacent tissues was observed in most of the lesions, and Cytophaga psychrophila has been detected in the vascular system in previous studies (Wood \& Yasutake 1956).

Fish with acute Cytophaga psychrophila infections (cold-water disease) often have caudal lesions that extend to the vertebrae. As with certain domestic mam- 


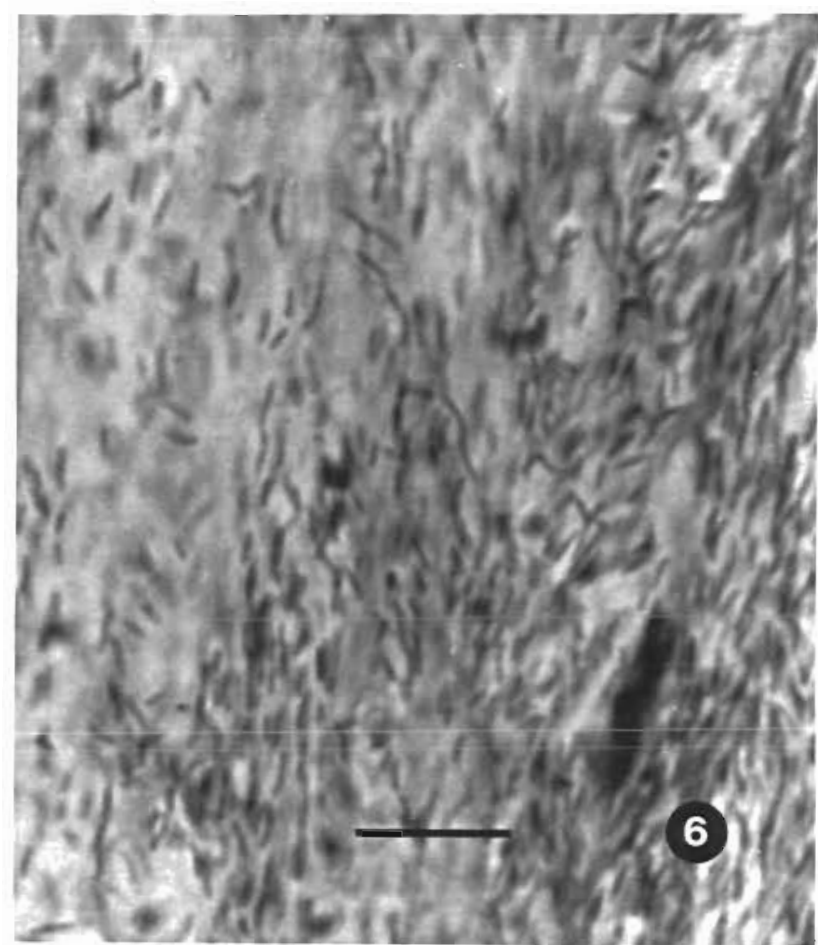

Fig. 6. Oncorhynchus kisutch. Notochord with numerous filamentous bacteria. Giemsa. Bar $=10 \mu \mathrm{m}$

\section{LITERATURE CITED}

Borg, A. (1960). Studies on myxobacteria associated with diseases in salmonid fishes. J. Wildl. Dis. (microfiche) 8: 1-85 (2 microcards)

Conrad, J. F., DeCew, M. (1967). Observations on deformed juvenile coho salmon Fish. Commission of Oregon Briefs 13: 129

Daly, J. G., Stevenson, R. M. W (1985). Charcoal agar, a new growth medium for the fish disease bacterium Renibacterium salmoninarum. Appl. environ. Microbiol. 50: 868-871.

Holt, R. A. (1972). Characterization and control of Cytophaga psychrophila (Borg) the causative agent of low temperature disease in young coho salmon (Oncorhynchus kisutch). Master's thesis, Oregon State University, Corvallis

Holt, R. A. (1987). Cytophaga psychrophila, the causative agent of bacterial cold-water disease in salmonid fish. $\mathrm{Ph}$. D. thesis, Oregon State University, Corvallis

Humason, G. L. (1979). Animal tissue techniques. W. H. Freeman Co. San Francisco

Jubb, K. V. F., Kennedy, P. C., Palmer, N. (1985). Pathology of domestic animals. Academic Press, New York

Luna, L. G. (1968). Armed Forces Institute of Pathologr manual of histological staining. McGraw-Hill, New Jork mals with tail lesions (Jubb et al. 1985), the neural lesions may have been initiated by localization of bacteria within the posterior vertebral column with subsequent transport to the anterior vertebrae and cranium in cerebrospinal fluid.

The disease described here, along with the scoljotic condition described by Conrad \& DeCew (1967), exemplifies the variety of pathological conditions that can be associated with Cytophaga psychrophila. Though a relatively small percentage of the population were affected, the poor prognosis indicates that this form of C. psychrophila disease is important to hatchery production under certain circumstances, and further studies to determine the conditions in which the disease is induced should be carried out.

Acknowledgements. This work was supported by Domsea Farms, Inc., Washington, the Battelle Memorial Institute, Corporate Technical Development Project Number B-0322-4051, Columbus, Ohio, and the Battelle Marine Science Laboratory. The Battelle Marine Science Laboratory is part of the Pacific Northwest Laboratory, which is operated for the US Department of Energy by Battelle Memorial Institute under Contract DE-AC06-76RLO 1830. We thank Drs S. F. Wellings and R. R. Pool for helpful comments on the histological material, and $M$. T Wilkinson for histological preparations and manuscript review.

Otis, E. J. (1984). Lesions of coldwater disease in steelhead (Salmo gairdneri): the role of Cytophaga psychrophila extracellular products. Master's thesis, University of Rhode Island, Kingston

Pacha, R. E., Ordal, E. J. (1970). Histopathology and experimental columnaris disease in young salmon. J. comp. Pathol. 77. 419-423

Schachte, J. H. (1983). Coldwater disease. In: Meyer, F. P.. Warren, J. W., Carey, T. G. (eds.) A guide to integrated fish. health management in the Great Lakes Basin. Special Publ. No. 83-2, Great Lakes Fish. Comm., Ann Arbor, Michigan, p. 193-197

Wolke, R. E. (1975). Pathology of bacterial and fungal diseases affecting fish. In: Ribelin, W E., Migaki, G. (eds.) The pathology of fishes. The University of Wisconsin Press, Madison, p. 33-116

Wood, E. M., Yasutake, W. T (1956). Histopathology of fish III. Peduncle (cold-water') disease. Prog. Fish Cult. 18: 58-61

Wood, J. W. (1974). Diseases of Pacific salmon and their prevention and treatment. Dept Fisheries, Olympia, Washington

Yasutake, W. T (1965). 'Whirling' sivers Abstracts of the 16th Ann. Northwest Fish Cult. Conf., Portland, Uregon, p. $36-37$ 